\title{
STRATEGI MENINGKATKAN MUTU PENDIDIKAN MELALUI PROGRAM KELAS EXCELLENT SMP PLUS DARUSSALAM BANYUWANGI
}

\author{
Nur Hidayati ${ }^{1}$, Wandariatul Maghfiroh ${ }^{2}$ \\ e-mail: nurhidayati875@gmail.com ${ }^{1}$, virohwanda28@ gmail.com ${ }^{2}$ \\ Prodi Manajemen Pendidikan Islam \\ Institut Agama Islam Darussalam Blokagung Banyuwangi
}

\begin{abstract}
Abstrak
Peningkatan mutu pendidikan merupakan salah satu pilar pokok dalam membangun pendidikan di Indonesia, karena jika pendidikan sudah bermutu, maka akan menghasilkan sumber daya manusia yang cerdas dan kompetitif. Dalam rangka meningkatkan mutu pendidikan perlu diselenggarakan salah satunya dengan pelayanan program pendidikan yang menampung kebutuhan siswa istimewa untuk mengoptimalkan potensi yang mereka miliki. Salah satu wadah bagi siswa istimewa salah satunya yakni dengan diadakannya program kelas excellent. Penelitian ini bertujuan untuk mengetahui strategi dalam meningkatkan mutu pendidikan melalui program kelas excellent di SMP Plus Darussalam Blokagung Tegalsari Banyuwangi. Subjek penelitian ini adalah kepala sekolah, WKS. Kurikulum serta kepala asrama kelas excellent yakni Al-Aziziyyah. Metode penelitian ini menggunakan deskriptif kualitatif, metode pengumpulan data melalui observasi, wawancara, dokumentasi, rekaman arsip serta perangkat fisik. Adapun keabsahan data menggunakan Kredibilitas (credibility), Transferabilitas (transferability), Depenabilitas (dependability), Konfirmabilitas (confirmability). Analisis data yang digunakan adalah analisis SWOT. Dari hasil penelitian ini strategi yang digunakan dalam meningkatkan mutu pendidikan melalui program kelas excellent di SMP Plus Darussalam Blokagung Tegalsari Banyuwangi meliputi: (1) Adanya proses seleksi secara selektif, (2) Meningkatkan kualitas guru, (3) Adanya study club dan vocab, (4) Adanya asrama khusus untuk siswi unggulan, (5) Adanya perpustakaan mini, serta (6) Memperkuat nilai plus dimasyarakat baik dalam hal akademik maupun non akademik.
\end{abstract}

\section{Kata Kunci: Strategi Mutu Pendidikan, Kelas Excellent}

\begin{abstract}
Improving the quality of education is one of the main pillars in building education in Indonesia, because if education is of good quality, it will produce intelligent and competitive human resources. In order to improve the quality of education it is necessary to organize one of them by providing educational program services that accommodate the needs of special students to optimize their potential. One of the forums for special students, one of which is the holding of an excellent class program.This study aims to determine the strategy in improving the quality of
\end{abstract}

Strategi Meningkatkan Mutu Pendidikan Melalui Program Kelas Excellent SMP Plus Darussalam Banyuwangi

Nur Hidayati, Wandariatul Maghfiroh 
education through the excellent class program at SMP Plus Darussalam Blokagung Tegalsari Banyuwangi. The subject of this research is the principal, WKS. The curriculum and the head of the excellent class dormitory are Al-Aziziyyah. This research method uses descriptive qualitative, data collection methods through observation, interviews, documentation, archival records and physical devices. The validity of the data uses credibility, transferability, dependability, and confirmability. The data analysis used is SWOT analysis. From the results of this study, the strategies used in improving the quality of education through the excellent class program at SMP Plus Darussalam Blokagung Tegalsari Banyuwangi include: (1) There is a selective selection process, (2) Improving the quality of teachers, (3) The existence of a study club, (4) The existence of a special dormitory for superior students, (5) The existence of a mini library, and (6) Strengthening the plus value in the community both in terms of academic and non-academic.

\section{Keywords: Education Quality Strategy, Excellent Class}

\section{A. Pendahuluan}

Kualitas hidup seorang manusia tergantung dari pendidikannya. Melalui proses tersebut, diharapkan manusia menjalankan tugas kehidupannya secara benar, karena hal itulah, fokus suatu pendidikan diarahkan pada kualitas logika, hati dan juga akhlak. Pendidikan merupakan hal yang paling utama dalam menentukan masa depan penerus bangsa, maka dari itu peran sekolah sebagai sumber ilmu pengetahuan harus dapat memberikan manfaatnya terhadap kecerdasan suatu bangsa. Al-Qur'an telah menjelaskan tentang pentingnya pendidikan, bahkan menempatkan manusia pada derajat yang tinggi jika mereka memiliki pengetahuan yang telah dijelaskan didalam Surat al-Mujadilah ayat 11 yang artinya: "Hai orang-orang beriman, apabila dikatakan kepadamu: 'Berlapang-lapanglah dalam majlis', maka lapangkanlah, maka Allah akan memberikan kelapangan bagimu. Dan jika dikatakan: 'Berdirilah kamu', maka berdirilah, maka Allah akan meninggikan di antara kamu orang-orang yang beriman dan orang-orang yang diberi ilmu pengetahuan beberapa derajat, dan Allah Maha Mengetahui apa yang kamu kerjakan”. (Departemen Agama RI, 2014:542)

Tafsir ayat ini Allah memerintahkan manusia untuk saling menjaga adab, dengan melapangkan tempat duduk bagi yang lain dalam sebuah majlis. Setiap orang 
lebih berhak terhadap tempat yang lebih dahulu ia tempati, namun dia dianjurkan untuk melapangkan tempat bagi saudaranya yakni orang dimuliakan dalam agama dan orang yang berilmu dapat duduk ditempat itu maka hendaklah mereka berdiri. Allah mengangkat derajat orang berilmu diantara kalian dengan kemuliaan didunia dan pahala diakhirat. Barang siapa beriman dan memiliki ilmu maka Allah akan mengangkat derajatnya dengan keimanan dan ilmunya (Tafsir Al-Madinah AlMunawwaroh, 2008:201).

Ayat diatas telah menjelaskan bahwa ilmu pengetahuan itu sangat penting. Karena dengan pengetahuan, manusia akan mengetahui baik buruk, benar salahnya sesuatu, serta agar siap bersaing dengan lainnya pengetahuan juga dapat dijadikan pedoman dalam menjalani aktivitas kehidupan. Dan untuk mendapatkan ilmu pengetahuan tersebut merupakan peran dari pendidikan.

Peningkatan mutu pendidikan merupakan salah satu pilar pokok dalam membangun pendidikan di Indonesia, karena jika pendidikan sudah bernutu, maka akan menghasilkan sumber daya manusia yang cerdasdan kompetitif.untuk mewujudkan program peningkatan mutu pendidikan yang berkelanjutan, maka hal tersebut diperjelas dengan adanya UU 20/2003 pasal 1 Nomor 17 tentang Sisdiknas yaitu 'Standar nasional pendidikan adalah kriteria minimal tentang sistem pendidikan di seluruh wilayah hukum Negara Kesatuan Republik Indonesia dan pasal 3 PP. 19 Tahun 2005 tentang SNP dalam Sanjaya (2016:7) menjelaskan 'Standar Nasional Pendidikan berfungsi sebagai dasar dalam perencanaan, pelaksanaan, dan pengawasan pendidikan dalam rangka mewujudkan pendidikan nasional yang bermutu.

Mutu sumber daya manusia menjadi salah satu modal utama dalam pelaksanaan sebuah pendidikan. Menyadari pentingnya kualitas SDM maka pemerintah dan masyarakat terus berupaya mewujudkan peningkatan mutu pendidikan antara lain, pengembangan dan perbaikan kurikulum, perbaikan sistem evaluasi, sarana pendidikan, pengembangan materi ajar, dan lain-lain. 
Dalam rangka meningkatkan mutu pendidikan perlu diselenggarakan salah satunya dengan pelayanan program pendidikan yang menampung kebutuhan siswa istimewa untuk mengoptimalkan potensi yang mereka miliki.Salah satu wadah bagi siswa istimewa salah satunya yakni dengan diadakannya program kelas excellent.Penelitian ini bertujuan untuk mengetahui strategi dalam meningkatkan mutu pendidikan melalui program kelas excellent di SMP Plus Darussalam Blokagung Tegalsari Banyuwangi.

\section{B. Metode Penelitian}

Penelitian ini mengunakan pendekatan kualitatif deskriptif, yaitu jenis penelitian yang berusaha memberikan data-data secara sistematis dan juga cermat tentang suatu fakta serta sifat (populasi) tertentu. Sugiyono (2020:9) mengatakan bahwa " metode penelitian kualitatif adalah metode penelitianya yang berlandasan pada filsafat postpositivme, yang mana hasil dari penelitian kualitatif lebih menekankan pada makna dari pada generalisasi yang berupa studi kasus adalah dikarenakan menggunakan lingkungan alamiah sebagai sumber data, lebih menekankan pada proses serta dalam studi kasus focus dalam mengembangkan deskripsi dan analis mendalam tentang permasalahan yang sedang diteliti. Penentuan lokasi ini dilakukan berdasarkan beberapa hal, diantaranya yaitu:

1. SMP Plus Darussalam Blokagung merupakan lembaga pendidikan berbasis pesantren

2. SMP Plus Darussalam Blokagung merupakan sekolah yang telah banyak memperoleh prestasi yang unggul

3. Tempat penelitian cukup strategis dan mudah dijangkau

4. Merupakan sekolah pertama diyayasan Darussalam yang mempunyanyai program kelas unggulan atau excellent.

Sesuai dengan fokus penelitian ini, maka yang dijadikan subyek atau informan adalah: 
1. Kepala sekolah SMP Plus Darussalam Blokagung, karena kepala sekolah sebagai leader lembaga tersebut, dan lebih berpengalaman serta mengetahui program-program atau strategi-strategi apa yang digunakan dalam rangka meningkatkan kualitas suatu pendidikan.

2. WKS. Kurikulum, dipilih sebagai informan dikarenakan WKS Kurikulum yang bertugas mengatur jadwal untuk program kelas excellent, dan juga lebih mengetahui tentang jadwal-jadwal tambahan untuk bimbingan belajar.

3. Kepala asrama SMP Plus Darussalam Blokagung program unggulan atau excellent, dipilih sebagai informan karena kepala asrama lebih mengetahui kegiatan sehari-hari siswa ketika diasrama, dan lebih tahu tentang kedisiplinan siswa saat di asrama seperti disiplin tidaknya para siswa mengikuti kegiatan asrama ataupun bimbingan belajar yang ada.

Dalam pengumpuan data ada beberapa teknik yang digunakan, menurut Yin (2014:103) pengumpulan data untuk studi kasus penelitian kualitatif berupa dokumen, rekaman arsip, wawancara, observasi dan perangkat fisik. Berikut penjelasan dari teknik pengumpulan data tersebut:

1. Observasi

Dalam melakukan observasi, peneliti memilih hal-hal yang diamati dan mencatat hal-hal yang berkaitan dengan strategi meningkatakan mutu pendidikan melalui program kelas excellent di SMP Plus Drussalam Blokagung.

\section{Wawancara}

Dalam penelitian ini wawancara akan dilakukan dengan narasumber/informan yakni kepala sekolah, WKS. Kurikulum serta kepala asrama kelas unggualan atau excellent/ asrama Al Aziziyyah.

3. Dokumentasi

Dalam hal ini penulis mengumpulkan data tertulis berupa dokumen tentang SMP Plus Darussalam Blokagung dan data-data penting lainnya yang berkaitan dengan pembahasan dalam penelitian ini. 
Analisis data menurut Bogdan dalam bukunya Sugiyono (2020:130) adalah proses mencari dan menyusun, dilakukan dengan cara sistematis, dari hasil kegiatan wawancara, catatan lapangan, dan dokumentasi, kemudian dikelompokkan ke dalam kategori, menyusun ke dalam pola, memilih mana yang penting guna mendukung data pokok yang akan dipelajari, membuat penarikan kesimpulan sehingga data yang ada mudah difahami dan temuanya dapat diinformasikan kepada orang lain. Analisis data yang digunakan dalam penelitian ini analisis SWOT.

Menurut Rangkuti (20014:18) analisis SWOT adalah suatu identifikasi mengenai faktor-faktor yang dilakukan secara sistematis guna merumuskan strategi yang ada pada perusahaan, guna mengetahui kekuatan, kelemahan, peluang dan ancaman yang ada pada SMP Plus Darussalam.

Menurut Rangkuti (2014:83) matriks SWOT adalah alat yang dipakai untuk menyusun factor-faktor strategi perusahaan. Matrik ini dapat menggambarkan secara jelas bagaimana peluang dan ancaman yang dihadapi SMP Plus Darussalam Bloakgung sehingga nantinya dapat disesuaikan dengan kekuatan dan kelemahan yang dimilikinya. Menurut Rangkuti (2014:21) matrik ini dapat menghasilkan empat kemungkinan alternatif strategi.

Tabel 1. Matriks SWOT

\begin{tabular}{|c|c|c|}
\hline IFAS & \multicolumn{1}{|c|}{$\begin{array}{c}\text { Kekuatan } \\
\text { (Strenghts) }\end{array}$} & Kelemahan (Weaknesses) \\
\hline $\begin{array}{c}\text { Peluang } \\
\text { (Opportunity) }\end{array}$ & $\begin{array}{c}\text { Strategi S-O } \\
\text { Memanfaatkan kekuatan } \\
\text { atas peluang yang telah } \\
\text { diidentifikasi }\end{array}$ & $\begin{array}{l}\text { Strategi W-O } \\
\text { Memperbaiki atau } \\
\text { meminimalkan kelemahan } \\
\text { guna memanfaatkan peluang }\end{array}$ \\
\hline $\begin{array}{c}\text { Anacaman } \\
\text { (Thraeths) }\end{array}$ & $\begin{array}{l}\text { Strategi S-T } \\
\text { Menciptakan Strategi W-T } \\
\text { menggunakan kekuatan } \\
\text { guna mengatasi ancaman }\end{array}$ & $\begin{array}{l}\text { Menciptakan strategi yang } \\
\text { meminimalkan kelemahan } \\
\text { guna menghindari ancaman }\end{array}$ \\
\hline
\end{tabular}

(Sumber: Rangkuti, 2014:21)

\section{Hasil dan Pembahasan}

Strategi Meningkatkan Mutu Pendidikan Melalui Program Kelas Excellent SMP Plus Darussalam Banyuwangi 
Menurut Usman dalam Abd. Rohman (2017:7) kata "manajemen" berasal dari bahasa latin "manus" yang berarti "tangan" dan "agere" yang berarti "melakukan". Dari dua kata tersebut dengan arti masing-masing yang terkandung di dalamnya merupakan arti secara etimologi. Selanjutnya kata "manus" dan "agere" digabung menjadi satu kesatuan kata kerja "managere" yang mengandung arti "menangani". Pengertian ini dalam ilmu ketatabahasaan disebut sebagai pengertian secara terminologi. "Managere" diterjemahkan ke dalam bahasa Inggris dalam bentuk kata kerja menjadi "to manage" dengan kata benda "management". Julukan bagi orang yang melakukan kegiatan managenent disebut manager atau manajer (dalam bahasa Indonesia). sedangkan dalam bahasa Prancis disebut "ménagement" yang berarti seni melaksanakan dan mengatur. Kata "management" dalam bahasa Indonesia diterjemahkan menjadi manajemen, yang mengandung arti “pengelolaan”. Pandangan George R. Terry dalam Abd. Rohman (2017:9) mengenai fungsi-fungsi manajemen lazim menggunakan akronim POAC, yaitu:

a. Planning (Perencanaan)

b. Organizing (Pengorganisiran)

c. Actuating (Pengaktualisasian)

d. Controlling (Pengawasan)

Kata strategi berasal dari Bahasa Yunani yaitu strategia (stratos=militer dan $a g=$ memimpin) yang berarti ilmu perang atau panglima perang. Strategia juga diartikan sebagai sebuah keterampilan dalam mengatur peristiwa.Sedangkan secara umum, strategi yaitu teknik dalam mencapai tujuan yang telah ditentukan. Menurut Sanjaya (2016:123) mengemukakan bahwa seorang yang berperang sebelum peperangan, ia akan menimbang kekuatan pasukannya baik dari segi kualitas ataupun kuantitas seperti kemampuan setiap orang, dan lain-lain guna untuk memenangkan sebuah peperangan. Menurut Sanjaya (2016:126) strategi adalah suatu perencanaan tentang serangkaian kegiatan yang didesain untuk mencapai tujuan yang telah ditentukan.Dalam Al Qur'an telah dijelaskan didalam Surah Al Hasyr ayat 18 yang Artinya: "Wahai orang-orang beriman, bertakwalah kamu pada Allah, dan 
hendaklah masing-masing dari kalian memperhatikan apa yang sudah diperbuatnya untuk hari besok (akhirat), dan bertakwlah kamu pada Allah, Sesungguhnya Allah itu Maha mengetahui tentang apa yang kamu kerjakan”. (Departemen Agama RI, 2014:542)

Quraish Shihab dalam tafsir "al-Misbah" nya memberi penafsiran bahwasannya ayat tersebut membahas mengenai strategi atau suatu perencanaan. Dikatakan oleh beliau lafadz “waltandzur'nafsumma koddamat lighod”, yang artinya bahwa manusia harus memikirkan bagi dirinya senidiri dan merencanakan perbuatan yang menyertainya selama hidup, sehingga akan mendapatkan kenikmatan kehidupan ini. Ayat di atas menjelaskan bahwa strategi adalah suatu penentuan rencana oleh pemimpin yang mana berfokus pada tujuan suatu organisasi, disertai dengan penyusunan upaya agar bagaimana tujuan tersebut dapat bisa tercapai sesuai dengan rencana yang telah ditetapkan. Karena strategi merupakan bagian dari manajemen yang terpenting untuk suatu organisasi dalam mencapai tujuan tertentu dalam waktu jangka panjang.

Menurut Ansof dalam Sagala (2017:129) manjemen strategi ialah suatu pendekatan yang sistematis bagi suatu tanggung jawab manajemen, mengondisikan organisasi ke posisi yang dipastikan mencapai tujuan dengan cara yang akan meyakinkan keberhasilan yang berkelanjutan dan membuat perusahaan (sekolah) menjamin atau mengamankan format yang mengejutkan. Dari beberapa pendapat diatas dapat disimpulkan bahwa manajemen strategi adalah ilmu untuk merumuskan, mengimplementasikan dan mengevaluasi suatu keputusan organisasi untuk mencapai tujuannya.

Prinsip-prinsip untuk mensukseskan strategi menurut Irwan Purwanto (2018:80-81) ada beberapa cara dalam mensukseskan suatu strategi, diantaranya yakni:

a. Sebuah strategi tersebut haruslah konsisten dengan lingkungannya. Ikutilah apa yang berkembang di lingkungan masyarakat jangan melawan arus dalam suatu lingkungan yang memberi peluang untuk bisa bergerak maju. 
b. Lebih dari satu macam strategi. Melihat ruang lingkup dalam kegiatnnya.

c. Hendaknya strategi memfokuskan dan menyatukan yang menjadi sumber daya dan tidak mencerai berikan antara satu sumber daya dengan sumber yang lainnya.

d. Memusatkan pada apa yang menjadi kekuatannya bukan pada apa yang menjadi kelemahannya. Dan memanfaatkan suatu kelemahan untuk mengambil langkah yang tepat sehingga bisa menempati posisi kompetitif yang kuat.

e. Strategi hendaknya dikontrol sehingga tidak menimbulkan resiko yang terlalu besar.

f. Menyusun strategi di atas landasan suatu keberhasilan yang telah dicapai bukan diatas kegagalan.

g. Kesuksesan strategi ditandai dengan mendukungnya semua pihak dalam organisasi.

Dalam dunia pendidikan sebuah lembaga pendidikan harus bisa menunjukkan bahwa lembaga yang dikelolanya mampu memberikan penidikan yang bermutu kepada siswa/siswinya. Dalam konteks pendidikan, seseorang dapat mengatakan suau lembaga itu bermutu jika output/lulusan baik, gurunya baik, sarana prasarananya baik dan sebagainya. Fathurrohman dan Sulistyorini (2012:40) mutu adalah ukuran baik buruk sebuah benda, kadar, taraf atau derajat kepandaian, kecerdasan, dan sebagainya.

Dalam konteks pendidikan, mutu lebih mengarah pada input atau masukan, proses, luaran (output). Mutu masukan bisa dilihat dari berbagai sisi, Pertama, baik tidaknya kondisi masukan sumber daya manusia, yakni kepala sekolah, guru, siswa dan juga lainnya. Kedua, kriteria masukan material memenuhi atau tidak seperti buku-buku, sarana dan prasarana serta yang lainnya. Ketiga, memenuhi atau tidaknya krteria masukan yakni perangkat software, seperti peratran struktur organisasi dan juga deskripsi kerja. Keempat, mutu masukan yang bersifat kebuthan dan harapan, seperti visi, motivasi, dan lain-lain. 
Menurut Sagala dalam Fathurrohman dan Sulistyorini (2012:45) mutu pendidikan adalah gambaran dan karakteristik menyeluruh jasa pelayanan pendidikan secara internal, maupun eksternal yang menunjukkan kemampuannya, memuaskan kebutuhan yang diharapkan, atau yang tersirat mencakup input, proses dan output pendidikan. Jadi dapat disimpulkan bahwa mutu pendidikan adalah gambaran pelayanan pendidikan untuk memuaskan kebutuhan yang diharapkan.

Kualitas pendidikan sering ditandai dengan adanya kondisi sekolah yang baik, syarat-syarat telah terpenuhi dan komponen-komponen lain yang harus ada pada suatu lembaga pendidikan. Komponen tersebut seperti berupa masukan atau input, proses, output atau keluaran, tenaga kependidikan, srana prasarana dan biaya. Peningkatan mutu pendidikan ialah sasaran pembangunan pada bidang pendidikan nasional, serta merupakan bagian terpenting dari upaya meningkatkan kualitas seorang siswa. Dalam UU No. 20 tahun 2003 pasal 03 tentang Sistem Pendidikan Nasional (2012: 55 ) bahwa:

Pendidikan nasional berfungsi mengembagkan suatu kemampuan dan membentuk suatu watak serta peradaban suatu bangsa yang bermartabat, dalam rangka untuk mencerdaskan kehidupan suatu bagsa, yang bertujuan guna berkembagnya potensi seroarng peserta didik agar menjadi manusia yang beriman dan bertakwa kepada Tuhan Yang Maha Esa, berakhlak mulia, berilmu, cakap, mandiri, dan menjadi warga negara yang demokratis serta warga negara yang bertanggung jawab.

Menurut Sagala dalam Fathurrohman (2012: 55) lembaga pendidikan atau sekolah dapat dikatakan bermutu, apabila prestasi sekolah menunjukkan pencapaian yang tinggi dalam bidang:

1) Prestasi akademik, yaitu nilai raport dan nilai kelulusan memenuhi standar yang telah ditentukan.

2) Memilik nilai-nilai kejujuran, ketaqwaan , kesopanan serta mampu dalam mengapresiasi nilai-nilai budaya. 
3) Memiliki tanggung jawab yang tinggi, dan kemampuan yang diwujudkan dalam bentuk suatu ketrampilan, sesuai dengan standar ilmu yang ia terima saat di sekolah.

Istilah sekolah unggulan secara umum dapat didefinisikan sebagai suatu lembaga yang memiliki keunggulan atau kelebihan dibandingkan dengan lembagalembaga sekolah lainnya. Kelebihan tersebut dapat berupa keunggulan dalam hal yaitu: 1) target prestasi belajar lebih tinggi, 2) proses belajar-mengajar yang lebih efektif, 3) kualitas guru yang lebih baik, dan 4) fasilitas belajar yang memadai. Tentu saja, untuk mengusahakan keunggulan-keunggulan tersebut diperlukan dukungan dana yang cukup besar.

Adanya kelas ungulan merupakan implementasi dari UU Republik Indonesia Nomor 20 tahun 2003 tentang Sistem Pendidikan Nasional menyebutkan: "warga negara yang mempunyai suatu potensi kecerdsan dan bakat yang istimewa maka berhak mendapatkan suatu pendidikan khusus". Mengembangkan serta meningkatkan kualitas pendidikan, menghasilkan sumber daya manusia, meningkatkan kemampuan serta pengetahuan tenaga pendidik agar dapat menghadapi persaingan secara global dan menciptkan keunggulan yang kompetitif merupakan tujuan adanya program kelas unggulan.

Menurut Suhartono dan Ngadirun dalm Hanun (2016:7), kelas excellent atau unggulan adalah kelas yang telah dirancang untuk memberikan suatu pelayanan belajar yang memadai bagi siswa atau siswi yang mana siswa tersebut mempunyai kemampuan yang luar biasa. Tujuan adanya kelas unggulan salah satunya yaitu: 1) mengembangkan serta meningkatkan kualitas suatu lembaga pendidikan, 2) menghasilkan sumber daya manusia atau lulusan yang berkualitas, 3) meningkatkan kemampuan serta pengetahuan bagi tenaga pendidik, 4) mengembagkan potensi yang telah dimiliki oleh sebuah sekolah, 5) meningkatkan kemampuan dalam menghadapi persaingan di dunia pendidikan dengan cara menciptakan keunggulan-keunggulan yang kompetitif. 
Tuntutan peran terhadap siswa kelas unggulan yaitu harapan memiliki nilai bagus, mempertahakan keunggulan sekolah, serta memiliki sikap dan juga tingkah laku yang baik. Namun kenyataanya, adanya tuntutan dalam peran ini dimunculkan dengan pemberian suatu label untuk mereka yang berada di kelas unggulan dari orang-orang yang berada disekitarnya, sehingga muncul label yang bersifat negatif dan ada pula yang bersifat positif. Label yang positif peserta didik merasa lebih percaya diri dan berharga terhadap kemampuannya, sedangkan yang berlabel negatif peserta didik lebih terbebani terhadap tuntutan yang mengharuskan mereka lebih pandai dari kelas lain.

Dalam penyelenggaraan kelas unggulan ini, disamping memiliki tujuan yang sangat ideal, tentunya juga memiliki beberapa karakteristik dasar yang kemudian menjadi ciri khas dari keberadaan kelas unggulan serta menjadi pembeda dengan kelas yang lainnya (kelas reguler).

Dalam meningkatkan mutu pendidikan, suatu lembaga mempunyai program tersendiri dalam hal ini. Dengan melihat fenomena perkembangan dan persaingan antar sekolah yang semakin meningkat, sekolah dituntut untuk dapat menerapkan berbagai strategi unggul dalam menghadapi pesaing. Salah satunya melalui program kelas unggulan atau kelas excellent. Dengan adanya kelas excellent, suatu lembaga memberikan kesempatan kepada siswa yang memiliki kecerdasan diatas rata-rata normal daripada siswa yang lainnya. Dengan adanya hal itu, maka lembaga pendidikan banyak yang mendirikan kelas excellent, salah satunya adalah SMP Plus Darussalam.

Dengan adanya program tersebut, SMP Plus Darussalam berupaya membuat strategi untuk meningkatakan mutu pendidikannya melalui program kelas excellent tersebut. Strategi sendiri adalah suatu ilmu atau langkah guna mencapai sebuah maksud dan tujuan yang telah direncanakan. Strategi yang digunakan oleh SMP Plus Darussalam Blokagung melalui program kelas excellent dapat meningkatkan mutu pendidikan lembaga guna melakukan perubahan menuju kebaikan. Perubahan harus dilakukan secara mandiri, karena tidak mungkin pihak luar ikut mendorong 
perubahan sementara dirinya sendiri tidak melakukan suatu perubahan.Hal ini senada dengan ayat Al-Qur'an dalam surah Ar-Ra'd ayat 11 yang berbunyi yang artinya: "Sesungguhnya Allah tidak akan mengubah keadaan suatu kaum sebelum mereka mengubah keadaan mereka sendiri” (Departemen Agama RI, 2014:542).

Tafsir ayat ini Allah memberi tahu bahwa Ia tidak mengubah suatu kaum sehingga salah satu diantara mereka ada yang mengubahnya. Bisa jadi dari golongan mereka sendiri, pengamat atau factor penyebab yang masih mempunyai hubungan sebagaimana para pasukan yang dikalahkan pada saat perang Uhud disebabkan penyelewengan yang dilakukan oleh ahli panah (Tafsir Al-Qurtubi, 2014: 294).

Dari ayat dan tafsir diatas dapat disimpulkan bahwa perubahan menuju yang lebih baik sangatlah penting, dan perubahan tersebut haruslah dilakukan dari pihak lembaga dengan melakukan berbagai strategi yang dilakukan.Langkah yang dipilih guna mengetahui faktor internal yang dimiliki oleh SMP Plus Darussalam Blokagung yaitu : melalui matriks IFAS yang meliputi kekuatan dan kelemahan dengan penjabaran sebagai berikut :

1. Kekuatan (Strength)

Kekuatan yang dimaksud adalah segala keunggulan yang memang dimiliki SMP Plus Darussalam Blokagung, yaitu :

a. Identitas lembaga yakni sekolah berbasis pondok pesantren.

Dengan figur lembaga sekolah yang berbasis pesantren tentu akan menjadikan SMP Plus Darussalam mempunyai nilai lebih disbanding dengan lembaga yang lainnya, sehingga masyarakat yang beragama Islam khususnya akan lebih tertarik memilih SMP Plus Darussalam sebagai tempat pendidikan anak mereka.

b. Sumber Daya Manusia yang professional

Sumber Daya yang professional sangat berperan penting sebagai pelaku dalam kegiatan pendidikan yakni dalam memberika pelayanan kepada warga sekolah, dengan didukung para staf dan guru yang rata-rata lulusan dari pondok, dalam hal ini akan mendukung dalam suatu lembaga. 
c. Kompetensi Lulusan yang dapat menerima peserta didik kesekolah yang akan dituju.

Kompetensi lulusan SMP Plus Darussalam yang tidak hanya unggul dalam hal akademik, namun juga akademik dapat membantu peserta didik dalam melanjutkan sekolah yang dituju dengan adanya kompetensi yang dimiliki mereka baik dari sekolah maupun dari pondok sendiri.

d. PP. Darussalam memiliki santri terbanyak se Kabupaten Banyuwangi

Hal ini menunjukkan bahwa PP. Darussalam mendapatkan kepercayaan dari masyarakat untuk menempatkan putra-putrinya di PP. Darussalam Blokagung.

e. Adanya asrama khusus program kelas excellent

Dengan adanya asrama khusus kelas excellent, program bisa dibagi mana yang dijalankan di sekolah dan mana yang diasrama, sehingga kegiatan bisa maksimal. Dengan adanya asrama tersendiri untuk para siswa kelas excellent, sehingga memudahkan untuk mengatur kegiatan yang diadakan. Dengan adanya asrama khusus ini merupakan salah satu alasan siswa berminat untuk program kelas excellent.

f. Adanya perpustakaan mini milik sendiri

Dengan adanya perpustakaan mini yang merupakan milik lembaga sendiri memudahkan para siswa untuk mendapatkan referensi dari tugastugas sekolah mereka.

g. Adanya laboratorium dan sarana praktek milik sendiri.

Laboratorium yang dimiliki meliputi laboratorium IT, IPA serta sarana praktek IPA sehingga memudahkan jadwal praktek tanpa takut akan berbenturan jadwal dengan lembaga lain.

2. Kelemahan (Weakness)

Kelemahan yang dimaksud merupakan keterbatasan yang ada dan dimiliki oleh SMP Plus Darussalam, yaitu : 
a. Kegiatan ekstrakurikuler, study club dan vocab sering berbenturan dengan kegiatan pondok pusat

Para siswa excellent SMP Plus Darussalam Blokagung menenempat di asrama khusus, bukan dipondok pusat atau ponok induk. Oleh karena itu asrama memiliki kegiatan atau program yang sedikit berbeda, tapi masih dibawah aturan pondok pusat. Terkadang kegiatan yang sudah dijadwalkan harus berbenturan dengan kegiatan pondok pusat yang mengharuskan kegiatan yang sudah terjadwal harus mengalah atau diganti.

b. Program harus sinkron dengan unit lain karena masih satu Yayasan

Program atau kegiatan yang dilakukan harus sinkron dengan unit lain karena masih dibawah satu Yayasan Darussalam, dalam hal ini lembaga sekolah tidak boleh sewenng-wenang dalam mengadakan suatu program sekolah yang bisa saja mengganggu proses pembelajaran unit yang lainnya.

c. Fasilitas yang harus berbagi dengan unit lain.

Gedung pendidikan tempat para belajar siswa SMP Plus Darussalam Blokagung serta fasilitas lainnya menjadi satu dengan unit lainnya, oleh karena itu gedung pendidikan harus berbagi. Masing-masing unit sudah ditentukan ruang dan fasilitas yang digunakan.

d. Adanya sikap membandingkan pada siswa dengan lembaga lain

Darussalam memiliki beberapa unit pendidikan, yang setingkat dengan SMP Plus Darussalam yakni Mts dan Muaddalah. Karena lembaga yang masih satu lingkungan, akhirnya timbul persepsi siswa saling membandingkan antar lembaga.

e. Shock culture

Merupakan suatu perasaan bingung, cemas serta gelisah ketika bermukim dilingkungan masyarakat yang baru dan total beda dengan situasi 
biasanya. Hal ini menyebabkan santri baru tidak betah berada di pondok pesantren sehingga mereka banyak yang boyong (pulang kerumah).

Langkah yang dipilih guna mengetahui factor eksternal yang dimiliki oleh SMP Plus Darussalam Blokagung yaitu melalui matriks EFAS meliputi peluang dan ancaman dengan penjabaran sebagai berikut :

1. Peluang (Opportunities)

Kesempatan yang dapat dimanfaatkan SMP Plus Darussalam utuk mencapai target lembaga :

a. Santri baru dari berbagai daerah Indonesia

SMP Plus Darussalam Blokagung merupakan lembaga dibawah Yayasan Pondok Pesantren Darussalam Blokagung yang mana santrinya dari berbagai daerah, yang mana santri memiliki keberagaman dan kemampuan yang berbeda-beda.

b. Teknologi yang terus berkembang

Perkembangan teknologi memberikan peluang kepada SMP Plus Darussalam untuk mengenalkan lembaga sekolahnya kepada masyarakat melalui media online terutama dalam program excellent yang dimiliki.

c. Permintaan/Minat dari masyarakat yang tinggi

Adanya tuntutan dari masyarakat yang menjadi salah satu alasan diadakannya program excellent tahfidz, yang mana awalnya SMP Plus Darussalam hanya menyediakan program kelas excellent SAINS.

2. Ancaman (Threats)

Ancaman SMP Plus Darussalam Blokagung Darussalam sebagai berikut:

a. Persaingan dari unit SLTP lain yang menyediakan kelas excellent baik yang masih satu yayasan maupun se Kabupaten Banyuwangi

Adanya lembaga lain yang menyediakan kelas excellent memberikan dampak tersendiri bagi SMP Plus Darussalam, karena memungkinkan masyarakat memilih lembaga yang lainnya.

b. Program kelas excellent yang sejenis dari unit SLTP lain. 
Dengan adanya program kelas excellent yang sejenis dari lembaga lain, hal ini akan berdampak pada minat masyarakat untuk memilih program kelas yang sama dari pihak lembaga sekolah yang lain.

Setelah mengetahui factor internal dan eksternal dari SMP Plus Darussalam Blokagung, dilakukan penerapan menggunakan matriks SWOT, yang menghasilkan empat kemungkinan alternatif yang dimiliki oleh SMP Plus Darussalam Blokagung yakni strategi S-O (Strenghts-Opportunities), Strategi W-O (WeaknessesOpportunities), Strategi S-T (Strengths-Threaths) Strategi W-T (Weaknesses-Treaths) dengan penjabaran sebagai berikut:

\section{Strategi S-O (Strenghts-Opportunities)}

Memanfaatkan kekuatan atas peluang yang telah diidentifikasi :

a. Proses seleksi secara selektif untuk siswa kelas excellent

Dikarenakan Darussalam berasal dari berbagai daerah, sehingga para santrinya pun juga memiliki kemampuan yang berbeda-beda, maka seleksi kelas siswa excellent harus diadakan secara ketat dan selektif untuk medapatkan hasil yang terbaik.

b. Meningkatkan kualitas guru

Dalam rangka meningkatkan kualitas Sumber Daya Manusia terutama guru, SMP Plus Darussalam Blokagung mengikuti kegiatan seminar atau workshop baik secara langsung maupun online.

c. Penambahan jam pada mata pelajaran yang difokuskan

Penambahan jam pada muatan kurikulum kelas excellent, yakni penambahan jam pada mata pelajaran SAINS untuk program kelas excellent SAINS, serta jam muroja'ah untuk program kelas excellent tahfidz.

d. Memaksimalkan Study Club dan vocab di asrama

Merupakan jam tambahan diluar jam pelajaran sekolah yang diselenggarakan di asrama khusus siswa kelas excellent untuk lebih meningkatkan akademik para siswa kelas excellent. 


\section{Strategi W-O (Weaknesses-Opportunities)}

Meminimalkan kelemahan guna memanfaatkan peluang :

a. Adanya sosialisai agar tidak saling membandingkan

Dengan adanya unit lain yang masih satu lingkup, mengakibatkan dampak adanya saling membandingkan pada siswa. Oleh karena itu, agar tidak adanya sikap saling membandingkan pada siswa, harus ada pendekatan untuk memberikan kefahaman pada para peserta didik.

b. Adanya bimbingan konseling santri baru untuk mengurangi Shock Culture

Hal ini dilakukan kepada santri baru agar mereka cepat beradaptasi dengan cara memberikan pemahaman kepada mereka.

c. Melengkapi fasilitas asrama khusus untuk program kelas excellent

Melengkapi sarana dan prasaran yang berada di asrama kelas excellent agar egiatan berjalan dengan baik dan lancer serta maksimal.

\section{Strategi S-T (Strengths-Threaths)}

Menciptakan strategi yang mnggunakan kekuatan guna mengatasi ancaman :

a. Meningkatkan kegiatan yang telah berjalan.

Kegiatan yang telah berjalan yang tidak mungkin dirubah, salah satunya dengan cara meningkatkan motivasi warga sekolah agar lebih semangat dalam menjalankan program yang telah berjalan.

b. Melengkapi fasilitas perpustakaan mini

Adanya perpustakaan milik pribadi merupakan salah satu cara SMP Plus Darussalam memiliki kelebihan dibandingkan lembaga yang lainnya. Dengan melengkapi fasilitas perpustakaan mini mulai dari buku dan yang lainnya untuk meningkatkan minat siswa dalam membaca.

\section{Strategi W-T (Weaknesses-Treaths)}

Meminimalkan kelemahan guna menghindari ancaman :

a. Mempertahankan mutu yang telah dicapai 
Mempertahankan mutu yang telah tercapai adalah suatu tugas bagi lembaga, bagaimana menjaga kepercayaan masyarakat terhadap suatu lembaga tersebut.

b. Memperkuat niai plus dimasyarakat dalam hal akademik maupun non akademik

Dengan adanya study club diharapkan menambah akademik para siswa kelas excellent, begitu juga dengan adanya ekstrakurikuler yang diadakan baik disekolah atau asrama untuk meningkatkan skill para siswa yang memiliki bakat.

\section{Kesimpulan}

Kesimpulan dari penelitian terkait strategi meningkatkan mutu pendidikan melalui program kelas excellent di SMP Plus Darussalam Blokagung, yaitu (1) Melalui strategi S-O (Strenghts-Opportunities), yakni dalam memanfaatkan kekuatan atas peluang yang telah diidentifikasi : SMP Plus Darussalam Blokagung melakukan proses seleksi secara selektif karena siswa SMP Plus Darussalam Blokagung dari berbagai daerah, adanya penambahan jam pada mata pelajaran yang menjadi focus program excellent yakni pelajaran SAINS dan muroja'ah, serta memaksimalkan study club dan vocab diasrama yang membantu siswa mendapat pelajaran lebih diluar jam sekolah. (2) Melalui strategi W-O (Weaknesses-Opportunities) yakni dalam meminimalkan kelemahan guna memanfaatkan peluang : SMP Plus Darussalam Blokagung memberikan pengarahan atau sosilisasi pada siswa, serta memberikan bimbingan konseling pada siswa agar cepat beradaptasi pada lingkungan baru, serta melengkapi fasilitas asrama khusus untuk program kelas excellent. (3) Melalui strategi S-T (Strenght-Treaths) yakni dalam menggunakan kekuatan guna mengatasi ancaman : SMP Plus Darussalam Blokagung meningkatkankegiatan yang telah berjalan, serta dibangunnya perpustakaan mini untuk siswa agar menamabha minat baca siswa SMP Plus Darussalam. (4) Melalui strategi W-T (Weaknesses-Treaths) yakni dalam meminimalkan kelemahan guna menghndari anacaman : SMP Plus 
Darussalam Blokagung harus mempertahankan mutu yang telah dicapainya, serta memperkuat niai plus dimasyarakat dalam hal akademik maupun non akademik.

\section{E. Daftar Pustaka}

Al-Qur'anul Karim, Kemenag RI. 2014. Al Quddus. Depok: Arya Duta.

Barnawi dan Muh.Arifin, 2013.Branded School.Jakarta: Ar-Ruzz Media.

Busro. 2008. Upaya Peningkatan Mutu Pendidikan Melalui Program Kelas Akselerasi di SMA Negeri 1 Pamulang Tangerang. Skripsi. Jakarta: Program Sarjana Ilmu Tarbiyah dan Keguruan UIN Syarif Hidayatullah Jakarta.

Creswell, John W. 2015. Penelitian Kualitatif \& Desain riset. Yogyakarta.: Pustaka Pelajar.

Fathurrohman, Muhammad. Dkk. 2012. Implementasi Manajemen Peningkatan Mutu Pendidikan Islam. Yogyakarta: Teras.

Furqon Hidayat, Ahmad: 2018. Manajemen Strategi Penigkatan Mutu Pendidikan di SDN Kalisat 01 Jember.Skripsi. Malang: Program Pascasarjana Universitas Islam Negeri Maulana Malik Ibrahim.

Kompri. 2015. Manajemen Pendidikan (Komponen-Komponen Elementer Sekolah).Yogyakarta: Ar-Ruzz Media.

Purwanto, Iwan. 2018. Manajemen Strategi. Bandung: Yrama Widya.

Rangkuti, Freddy. 2014. Analisis SWOT: Teknik Membedah Kasus Bisnis. Jakarta: PT Gramedia Pustaka Utama.

Rohman, Abd. 2017. Dasar-Dasar Manajemen. Malang: Intelegensia Media.

Sagala, Syaiful. 2017. Manajemen Strategik daam Peningkatan Mutu Pendidikan. Bandung: Alfabeta

Sanjaya, Wina. 2016. Strategi Pembelajaran.. Jakarta: Kencana Prenamadia Group.

Shobri, Muwafiqus. 2017. Strategi Meningkatkan Mutu Pendidikan di Madrasah Aliyah Hasan Jufri Jurnal Studi Keislaman, 3(1): 13.

Somantri, Manap. 2014. Perencanaan Pendidikan. Bandung: IPB Press. 
Sugiyono. 2020. Metode Penelitian Kualitatif. Bandung: Alfabeta.

Suhartono dan Ngadirun. 2016. Penyelenggaraan Program Kelas Unggulan di Sekolah Dasar. Jurnal Pendidikan,6(2).

Trisandi. 2020. Strategi Kepala Sekolah dalam Mewujudkan Kelas Unggulan (International Plus Class) di SMA Sains Al-Qur'an Wahid Hasyim Yogyakarta Jurnal Pendidikan Dompet Dhuafa, 10(1):29-30.

Tusadiyah, Ella: 2019. Strategi Perencanaan Pendidikan Dalam Upaya Meningkatkan Kualitas Pendidikan Di SMP Plus Darussalam Blokagung Banyuwangi Tahun 2018/2019. Skripsi.Banyuwangi: Program Pascasarjana Ilmu Tarbiyyah dan Keguruan IAIDA Blokagung.

Yin, Robert K. 2014. Studi Kasus Desain dan Metode. Jakarta: Rajawali Pers.

Yulia Nurul Maulida: 2018. Manajemen Strategik dalam Meningkatkan Mutu Pendidikan di MTs Negeri 1 Grobogan. Skripsi. Program Sarjana Ilmu Tarbiyah dan Keguruan Universitas Islam Negeri Walisongo Semarang. 